\title{
Supporting Information to \\ Orientation of a Key Glutamine Residue in the BLUF Domain from AppA Revealed by Mutagenesis, Spectroscopy, and Quantum Chemical Calculations
}

\author{
Masashi Unno, Shinji Masuda, Taka-aki, Ono, and Seigo Yamauchi \\ Institute of Multidisciplinary Research for Advanced Materials, Tohoku University, Sendai 980-8577, Japan, Graduate \\ School of Bioscience and Biotechnology, Tokyo Institute of Technology, Yokohama 226-8501, Japan, and Molecular \\ Membrane Biology Laboratory, The Institute of Physical and Chemical Research (RIKEN), 2-1 Hirosawa, Saitama \\ 351-0198, Japan
}

\section{Full Listing of Reference 18}

Frisch, M. J.; Trucks, G. W.; Schlegel, H. B.; Scuseria, G. E.; Robb, M. A.; Cheeseman, J. R.; Montgomery, Jr., J. A.; Vreven, T.; Kudin, K. N.; Burant, J. C.; Millam, J. M.; Iyengar, S. S.; Tomasi, J.; Barone, V.; Mennucci, B.; Cossi, M.; Scalmani, G.; Rega, N.; Petersson, G. A.; Nakatsuji, H.; Hada, M.; Ehara, M.; Toyota, K.; Fukuda, R.; Hasegawa, J.; Ishida, M.; Nakajima, T.; Honda, Y.; Kitao, O.; Nakai, H.; Klene, M.; Li, X.; Knox, J. E.; Hratchian, H. P.; Cross, J. B.; Bakken, V.; Adamo, C.; Jaramillo, J.; Gomperts, R.; Stratmann, R. E.; Yazyev, O.; Austin, A. J.; Cammi, R.; Pomelli, C.; Ochterski, J. W.; Ayala, P. Y.; Morokuma, K.; Voth, G. A.; Salvador, P.; Dannenberg, J. J.; Zakrzewski, V. G.; Dapprich, S.; Daniels, A. D.; Strain, M. C.; Farkas, O.; Malick, D. K.; Rabuck, A. D.; Raghavachari, K.; Foresman, J. B.; Ortiz, J. V.; Cui, Q.; Baboul, A. G.; Clifford, S.; Cioslowski, J.; Stefanov, B. B.; Liu, G.; Liashenko, A.; Piskorz, P.; Komaromi, I.; Martin, R. L.; Fox, D. J.; Keith, T.; Al-Laham, M. A.; Peng, C. Y.; Nanayakkara, A.; Challacombe, M.; Gill, P. M. W.; Johnson, B.; Chen, W.; Wong, M. W.; Gonzalez, C.; Pople, J. A. Gaussian 03, Revision B.04, Gaussian, Inc., Wallingford CT, 2004.

\section{Materials and Methods}

Sample Preparations. The glutamine residue at position 63 of the AppA126 was changed to leucine by PCR primer mutagenesis using Pyrobest DNA polymerase (TaKaRa). The primers used were $\quad$ pET28-F, ${ }^{1}$ AppA126-R, ${ }^{2}$ AppA-Q63L-F (5'GGCGTCTTCTTCCTCTGGCTCGAAGGC-3') and AppAQ63L-R (5'-GCCTTCGAGCCAGAGGAAGAAGACGCC-3'). The AppA-Q63L-F and AppA-Q63L-R primers are the complementary primer pair to give a specific Q63L mutation (underlined). The first PCR was achieved with the two primer pairs pET28-F/AppA-Q63L-R and AppA126-R/AppA-Q63L-F, using the isolated plasmid pETAppA $156^{1}$ as a template DNA. The two DNA fragments from the first PCR were mixed and then used as template for the second PCR amplification using the primer pair pET28-F/AppA126-R. The second PCR product was digested with $N d e \mathrm{I}$ and EcoRI, and cloned into NdeI-EcoRI-cut pTYB12 vector (New England BioLabs). The resulting plasmid pTYAppA126-Q63L was used to transform E. coli strain BL21(DE3) (Novagen), and the resulting strain was used to express AppA126 Q63L mutant protein. Purification of wild type and Q63L mutant proteins were performed as described previously. ${ }^{2}$

Spectroscopy. Raman spectra were obtained as described previously $^{3}$ on a Spex 500M spectrometer equipped with a liquid nitrogen-cooled CCD detector (Instrument S.A., Inc.). Rayleigh scattering was rejected with a Triax190 spectrometer (Instrument S.A., Inc.). Samples were excited with the $647.1 \mathrm{~nm}$ line available from a krypton ion laser (BeamLok 2065, Spectra-Physics Lasers, Inc.). The measurements were made on samples contained in a 1.5 x $1.5 \times 48 \mathrm{~mm}$ quartz cuvette at room temperature $\left(\sim 25^{\circ} \mathrm{C}\right)$. UVvisible absorption spectra were recorded on a Shimazu MultiSpec1500 photodiode array spectrophotometer as described previously. ${ }^{4}$

DFT Calculations. The optimized geometry and harmonic vibrational frequencies were calculated using the Gaussian03 program. ${ }^{5}$ The hybrid functional B3LYP and the $6-31 \mathrm{G}^{* *}$ basis set were used for these calculations. The calculated frequencies were scaled using a factor of 0.9613. A time-dependent density functional theory (TD-DFT) with the $6-31 \mathrm{G}^{*}$ basis set was used for estimating the UV-visible absorption spectra.

\section{Additional Results and Discussion}

UV-visible Absorption and Raman Spectra. Figure S1 displays the UV-visible absorption spectra of the Q63L mutant of AppA126 and examines the effect of illumination by a blue light. In contrast to WT AppA126, ${ }^{1,2}$ the Q63L mutant exhibits no spectral changes during illumination. Figure S2 shows the Raman spectra of WT AppA126 and the Q63L mutant at $647.1 \mathrm{~nm}$ excitation. The upper two traces are the spectra for the samples in $\mathrm{H}_{2} \mathrm{O}$ buffer, whereas the lower ones are the spectra for the samples in $\mathrm{D}_{2} \mathrm{O}$ buffer. As shown in the figure, the Q63L mutation upshifts the $v_{10}$ frequency by $4-5 \mathrm{~cm}^{-1}$.

DFT Calculations. Table $\mathrm{S} 1$ summarizes the computed frequencies of $v_{12}, v_{13}, v_{14}$, and $v_{15}$ for models 1,2 , and $3 x(x=\mathrm{A}$, $\mathrm{B}$, and $\mathrm{C})$.

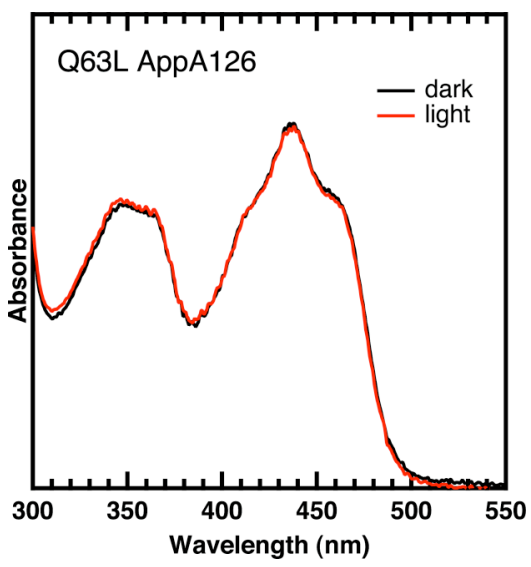

Figure S1. UV-visible absorption spectra of dark-adapted (black line) and light-illuminated (red line) Q63L mutant of AppA126 in $50 \mathrm{mM}$ Tris- $\mathrm{HCl}$ and $1 \mathrm{mM} \mathrm{NaCl}$ at $\mathrm{pH}$ 8.0. 


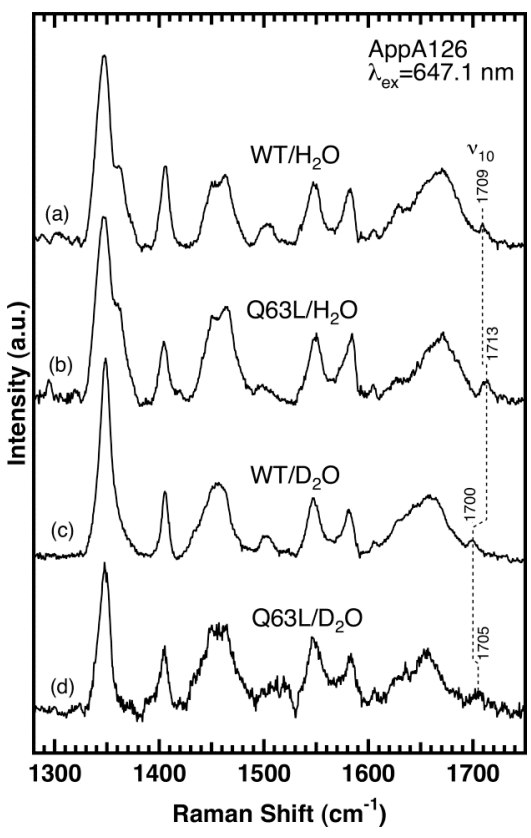

Figure S2. Raman spectra of wild-type AppA126 and the Q63L mutant. Excitation wavelength was $647.1 \mathrm{~nm}$. (a) WT AppA126 in $\mathrm{H}_{2} \mathrm{O}$ buffer. (b) WT AppA126 in $\mathrm{D}_{2} \mathrm{O}$ buffer. (c) Q63L AppA126 in $\mathrm{H}_{2} \mathrm{O}$ buffer. (d) Q63L AppA126 in $\mathrm{D}_{2} \mathrm{O}$ buffer. A buffer composition and $\mathrm{pH}$ were $50 \mathrm{mM}$ Tris$\mathrm{HCl}(\mathrm{DCl}), 1 \mathrm{mM} \mathrm{NaCl}$ and $\mathrm{pH}(\mathrm{pD})$ 8.0.

Table S1. Calculated Vibrational Frequency $\left(\mathrm{cm}^{-1}\right)$ of the Active Site Models for BLUF Proteins ${ }^{a}$

\begin{tabular}{llllll}
\hline & model 1 & model 2 & model 3A & model 3B & model 3C \\
\hline$v_{12}$ & $1618(-1)$ & 1617 & $1617(0)$ & $1618(-1)$ & $1618(-1)$ \\
$v_{13}$ & $1572(-2)$ & 1570 & $1565(5)$ & $1569(1)$ & $1568(2)$ \\
$v_{14}$ & $1529(0)$ & 1529 & $1526(3)$ & $1530(-1)$ & $1529(0)$ \\
$v_{15}$ & $1516(-1)$ & 1515 & $1510(5)$ & $1515(0)$ & $1512(3)$ \\
\hline
\end{tabular}

${ }^{a}$ The numbers in the parentheses are the shifts of model $2-$ model 1 or $3 x(x=\mathrm{A}, \mathrm{B}$, or $\mathrm{C})$.

Comments on Analogous Glutamine Mutants. In this study, we have shown that replacement of Gln63 results in a lack of photosensitivity for AppA126 (Figure S1). This result is consistent with previous studies, where analogous mutants were examined for $\mathrm{T}^{110078^{6}}$ and PAC. ${ }^{7}$ However, the glutamine mutations of Gln50 $\rightarrow$ Ala (Q50A) for Tl10078 ${ }^{6}$ and Gln514 $\rightarrow$ Gly (Q514G) for $\mathrm{PAC}^{7}$ exhibit little spectral changes in the flavin absorption spectrum in the dark state, whereas the Q63L mutation for AppA126 causes $\sim 10 \mathrm{~nm}$ blue shifts (Figure 2A). Although the reason for the difference is not certain at present, we can point out that a volume of the side chain is significantly reduced by the Q50A or Q514G mutation, while the Q63L mutation is volume conserving. This suggests that the Q50A and Q514G mutations not only remove a hydrogen bond between the glutamine residue and the isoalloxazine ring but also cause additional structural changes in the active site. For example, the substitution of Gln with Ala or Gly will create a cavity near the chromophore. Formation of a cavity may allow an entry of a water molecule, which could form a hydrogen bond with the isoalloxazine ring. This interpretation is consistent with the result for the Gln63 $\rightarrow$ Asn (Q63N) mutant of AppA126, where the size of the side chain is reduced. Similar to the case of Q50A and Q514G mutants, the UV-visible absorption spectrum of the Q63N mutant in the dark state is similar to that of WT AppA126, whereas this mutant does not show a photosensitivity like the Q63L.

\section{References}

(1) Kraft, B. J.; Masuda, S.; Kikuchi, J.; Dragnea, V.; Tollin, G.; Zalesky, J. M.; Bauer, C. E. Biochemistry 2003, 42, 6726-6734

(2) Masuda, S.; Hasegawa, K.; Ono, T. Biochemistry 2005, 44, 1215-12224.

(3) Unno, M.; Sano, R.; Masuda, S.; Ono, T.; Yamauchi, S. J. Phys. Chem. B 2005, 109, 12620-12626.

(4) Masuda, S.; Hasegawa, K.; Ishii, A.; Ono, T. Biochemistry 2004, 43 5304-5313.

(5) Frisch, M. J.; Trucks, G. W.; Schlegel, H. B.; Scuseria, G. E.; Robb, M A.; Cheeseman, J. R.; Montgomery, Jr., J. A.; Vreven, T.; Kudin, K. N.; Burant, J. C.; Millam, J. M.; Iyengar, S. S.; Tomasi, J.; Barone, V. Mennucci, B.; Cossi, M.; Scalmani, G.; Rega, N.; Petersson, G. A. Nakatsuji, H.; Hada, M.; Ehara, M.; Toyota, K.; Fukuda, R.; Hasegawa, J.; Ishida, M.; Nakajima, T.; Honda, Y.; Kitao, O.; Nakai, H.; Klene, M.; Li, X.; Knox, J. E.; Hratchian, H. P.; Cross, J. B.; Bakken, V.; Adamo, C.; Jaramillo, J.; Gomperts, R.; Stratmann, R. E.; Yazyev, O.; Austin, A J.; Cammi, R.; Pomelli, C.; Ochterski, J. W.; Ayala, P. Y.; Morokuma, K.; Voth, G. A.; Salvador, P.; Dannenberg, J. J.; Zakrzewski, V. G.; Dapprich, S.; Daniels, A. D.; Strain, M. C.; Farkas, O.; Malick, D. K.; Rabuck, A. D.; Raghavachari, K.; Foresman, J. B.; Ortiz, J. V.; Cui, Q. Baboul, A. G.; Clifford, S.; Cioslowski, J.; Stefanov, B. B.; Liu, G.; Liashenko, A.; Piskorz, P.; Komaromi, I.; Martin, R. L.; Fox, D. J.; Keith, T.; Al-Laham, M. A.; Peng, C. Y.; Nanayakkara, A.; Challacombe, M.; Gill, P. M. W.; Johnson, B.; Chen, W.; Wong, M. W.; Gonzalez, C.; Pople, J. A. Gaussian 03, Revision B.04, Gaussian, Inc., Wallingford CT, 2004

(6) Kita, A.; Okajima, K.; Morimoto, Y.; Ikeuchi, M.; Miki, K. J. Mol. Biol. 2005, 349, 1-9.

(7) Ito, S.; Murakami, A.; Sato, K.; Nishina, Y.; Shiga, K.; Takahashi, T.; Higashi, S.; Iseki, M.; Watanabe, M. Photochem. Photobiol. Sci. 2005, 4 762-769. 
